\title{
A STOCHASTIC APPROACH TO EVALUATE THE RELIABILITY OF URBAN PASSENGER TRANSPORTATION SERVICES
}

\author{
D. Kopytkov, Ph. D. (Eng.), \\ Kharkov National Automobile and Highway University
}

\begin{abstract}
An approach to estimate the reliability of urban passenger transport from the passengers' viewpoint has been presented, in which the parameter to be investigated is the fixed-route headway. The probability of passenger arrival to the destination point has been suggested as an indicator of the service reliability. The given approach makes it possible to evaluate the reliability of both single modes of the urban mass transit and the transportation system reliability as a whole.
\end{abstract}

Key words: urban mass transit, reliability, headway, law of distribution, arrival probability.

\section{ВЕРОЯТНОСТНЫЙ ПОДХОД К ОПРЕДЕЛЕНИЮ НАДЕЖНОСТИ ПРЕДОСТАВЛЕНИЯ УСЛУГ ГОРОДСКОГО ПАССАЖИРСКОГО ТРАНСПОРТА}

\author{
Д.М. Копытков, доц., к.П.н., \\ Харьковский национальный автомобильно-дорожный университет
}

\begin{abstract}
Аннотация. Предложена методика оценки надежности функиионирования городского пассажирского транспорта с точки зрения пассажиров, в которой исследуемым параметром является интервал движения на маршрутах.
\end{abstract}

Ключевые слова: надежность, интервал движения, вероятность прибытия в пункт назначения, закон распределения.

\section{ІМОВІРНІСНИЙ ПІДХІД ДО ВИЗНАЧЕННЯ НАДІЙНОСТІ НАДАННЯ ПОСЛУГ МІСЬКОГО ПАСАЖИРСЬКОГО ТРАНСПОРТУ}

\author{
Д.М. Копитков, доц., к.п.н., \\ Харківський національний автомобільно-дорожній університет
}

Анотація. Запропоновано методику оцінки надійності функиіонування міського пасажсирського транспорту з точки зору пасажирів, в якій досліджуваним параметром є інтервал руху транспортних засобів на маршрутах.

Ключові слова: надійність, інтервал руху, імовірність прибуття до пункту призначення, закон розподілу.

\section{Introduction}

The development of the urban passenger transportation (UPT) is of both economic and social significance. The economic consequences of urban passenger transportation functioning can be attributed to the effect obtained from the reduction of time losses in the material production and the non-productive sphere for the growth of social labor productivity, improving the quality of products by reducing the transport fatigue of workers, saving recourses for the development of social infrastructure due to its high concentration rate. The social consequences of transportation services are taken to an increase in the free time of passengers, the opportunities for using the services of cultural and public institutions, improving people's health, etc. 
One of the main goals of operation and further development of the mass transit industry is to improve the urban passenger transportation quality. The subjects to evaluate the service quality are the passengers, so, when assessing a task completion rate in the passenger transport operation, it is necessary to express the effect of qualitative changes from the passengers' viewpoint.

\section{Analysis of publications}

The issues of improving the customer service are closely related to the service quality problem. In the current market relations, it is proposed to introduce a consumer quality assessment for the service sector where a little experience has been accumulated yet.

In this area, the development of quality systems is limited to a technocratic approach in assessing the material resources, while the methods to evaluate the consumer effect have only begun to develop.

Concerning the urban passenger transportation, the need to ensure a high quality of passenger transport services is directly established by the regulations presented in $[1,2]$, most of which determine the complete satisfaction of the economy and population needs in passenger transportation as the main issue for mass transit operation.

If the reliability is considered as a single parameter of the urban transportation quality, then a technocratic approach prevails here, associated, first of all, with the reliability of technical systems, facilities or objects (for example, transportation systems, route network, vehicles or drivers) [3, 4]. In study [5] this value is considered as only a sum of average travel time and standard deviation. The papers $[6,7]$ give an approach from the consumer theory not explaining a stochastic nature of this quality indicator. Some authors say that parameter is considered as one of the components of transportation quality without giving the calculation technique [8]. The works [9-12] only demonstrate the indicator importance for passengers from various transport surveys but also not to provide any determination methodology. The earlier studies $[13,14]$ express this indicator as the «actual reliability values-to-normative ones» ratio that, in most cases, is difficult to be correctly determined.
Thus, the above-mentioned reliability assessment indicators, as a rule, describe the state and development of some urban transportation components and do not meet the passengers' requirements to the level of transportation services.

\section{Purpose and problem statement}

The objective of the study is to develop an approach to assess the reliability of urban passenger transportation services in current conditions for improving the system management efficiency.

To achieve this goal, it is necessary to conduct a full-scale survey to obtain the headways on the urban passenger transport routes.

\section{Approach to the urban passenger transportation reliability determination}

The functioning of urban passenger transportation is a stochastic process due to the influence of many disturbing effects, which are rather difficult to describe with strict analytical dependencies. In this case, good and consistent research results can be obtained by using the probabilistic approach and mathematical statistic methods including the public transportation reliability estimation [15].

From the above stated, the reliability of urban transportation is the probability for the passenger to arrive from the departure to the destination point within the expected time. On various routes the reliability of urban transport services must be assessed in the morning, «inter-peak» and evening peak-load periods $t_{j}$.

The actual headway of the fixed-route public transportation is a stochastic value distributed with a probability distribution law of a continuous random variable. Until the present day, there is no a common opinion in respect to the exact distribution law value. Thus, the authors $[16,17]$ believe it to be normally distributed, although the paper [18] showed the consideration of the «peak» and «inter-peak» hours was of great importance in the distribution law selection that resulted in impossibility of its unambiguous confirmation within the data obtained.

For the case under consideration, during a bus route No. 265 survey the 211 values of headway were obtained. In order to determine the influence of the vehicle operating hours' assignment («peak» and «inter-peak» hours) on the value, 
the null hypothesis was formulated that the mathematical expectations of the headways for various hours were the same. Due to this, a sin- gle-factor analysis of variance was done, the results of which are shown in table 1.

Table 1 Single-factor variance analysis results

\begin{tabular}{|l|c|c|c|c|c|c|}
\hline Variation source & Square sum & Degree of freedom & Mean square & $\begin{array}{c}F \text {-value } \\
\text { calculated }\end{array}$ & $p$-value & $\begin{array}{c}F \text {-critical } \\
\text { value }\end{array}$ \\
\hline Between groups & 1,423 & 2 & 0,711 & \multirow{2}{*}{0,182} & \multirow{2}{*}{0,833} & 3,039 \\
\cline { 1 - 4 } Within groups & 799,72 & 205 & 3,901 & & \\
\cline { 1 - 5 } Total & 799,883 & 207 & - & & & \\
\hline
\end{tabular}

As can be seen in table 1 , the calculated value of the Fisher test of 0,182 is much lower than the critical value of 3,039 . Consequently, at the $95 \%$ confidence limit, the null hypothesis on the equality of the mathematical expectations of the vehicle headway for different operating hours is to be accepted [19].

Thus, from the results of the variance analysis, in order to evaluate statistically there are no clear distinctions between the «peak» and «inter-peak» time windows.

For the headway values obtained, an attempt was made to fit the parameters of the normal distribution law in the Statistica software presented on fig. 1.

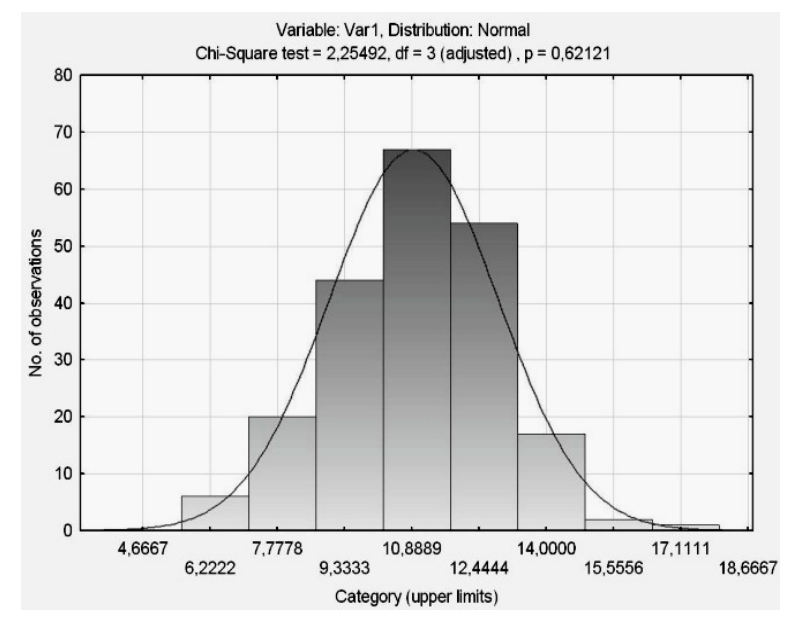

Fig. 1. Distribution fitting parameters

As can be seen from the comparison of empirical and theoretical frequencies under the «chisquare» test shown on fig. 1 is equal to 2,254, and the probability is of 0,621 , the hypothesis of the headway values to be normally distributed can be taken into consideration [20].
If the probability of the investigated event occurrence is equal to the integral of the probability density of the distribution, then

$$
p(x)=\int_{0}^{\infty} f(x) d x
$$

In case of the above-mentioned distribution, a stochastic value distributed in accordance with the normal law is described by the density [21]

$$
f(x)=\frac{1}{\sigma \sqrt{2 \pi}} \mathrm{e}^{-\frac{(x-a)^{2}}{2 \sigma^{2}}},
$$

where $a$ - the mathematical expectation of a random variable; $\sigma$ - the standard deviation of a random variable.

Due to this, it is necessary to determine that the probability of a continuous random variable, the measured actual vehicle headway, will take a value within the interval $[\alpha, \beta]$. The probability is equal to a definite integral of the distribution density from $\alpha$ to $\beta$ limits.

According to Laplace's theorem, this formula should be reduced to an equation that can be solved using the tables [21]

$$
p_{t j}\left(\alpha<x_{t j}<\beta\right)=F\left(\frac{\beta-a_{t j}}{\sigma_{t j}}\right)-F\left(\frac{\alpha-a_{t j}}{\sigma_{t j}}\right),
$$

where $p_{t j}$ - arrival probability at the destination point in the $j^{\text {th }}$ period; $x_{t j}$ - actual vehicle headway in the $j^{\text {th }}$ period, min; $\alpha, \beta$ - lower and upper headway limit, respectively, min; $a_{t j}-$ headway mathematical expectation in the $j^{\text {th }}$ period, min; $\sigma_{t j}$ - headway standard deviation in the $j^{\text {th }}$ period, min. 
It is necessary to determine the $[\alpha, \beta]$ interval limits. In making the lower limit, we assume that $\alpha$ is the minimum route headway that can be provided taking into account the passenger traffic and the road network capacity, i.e. $\alpha=1$ minute [22]. Under the study [23] the upper limit should not exceed 15 minutes, since the waiting time that is more this value adversely affects the mental and emotional state of the passenger. Regarding the urban transportation, the dependence (2) can be presented in a general form

$$
p_{t j}\left(0<x_{t j}<15\right)=F\left(\frac{\beta-a_{t j}}{\sigma_{t j}}\right)+F\left(\frac{a_{t j}}{\sigma_{t j}}\right) .
$$

Thus, this indicator comprises such significant components of the transport service quality as passenger-expected headway, mathematical expectation (the average headway value in case of large number of observations), and the headway standard deviation.

The probability to meet the headway for the $i^{\text {th }}$ route of the $j^{\text {th }}$ urban transportation mode should be calculated for the characteristic hours of its operation that is for the «morning», «inter-» and «evening» peak-load. Then the resulting reliability factor can be presented as

$$
k_{r e l}^{i j}=P\left(x_{j}\right)_{m p} \cdot P\left(x_{j}\right)_{i p} \cdot P\left(x_{j}\right)_{e p} .
$$

For a single urban mass transit system

$$
k_{r e l}^{j}=\prod_{i=1}^{n} k_{r e l}^{i}
$$

where $n$-number of routes in the $j^{\text {th }}$ mode.

And for the urban mass transit as a whole

$$
k_{r e l . U P T}^{j}=\prod_{j=1}^{n} k_{r e l}^{j},
$$

where $n$ - number of the urban mass transit modes.

The example of the single bus route reliability evaluation using the 211 headway values is given in table 2 without peak hours fragmentation.

As can be seen in table 2 with the observed average headway, standard deviation and passenger-expected headway limits, the probability of a random variable to be within the range (or the probability of arrival at the destination point) is 0,853 . In our opinion, the obtained values of the arrival probability or the urban transportation reliability rate can be also ranked within the following scale: $0,9-1-$ exemplary rate; $0,8-0,89-$ sufficient rate; $0,7-0,79$ - satisfactory rate; 0,69 and lower - unsatisfactory rate.

Table 2 Bus route reliability calculation

\begin{tabular}{|l|c|}
\hline \multicolumn{1}{|c|}{ Parameter name } & Value \\
\hline Lower headway limit, min & 1 \\
\hline Upper headway limit, min & 15 \\
\hline Headway expectation, min & 10,93 \\
\hline Standard deviation, min & 3,81 \\
\hline$F(1)$ ratio & 1,068 \\
\hline$F(2)$ ratio & $-2,603$ \\
\hline Laplace function $F(1)$ & 0,3577 \\
\hline Laplace function $F(2)$ & 0,4953 \\
\hline$F(1)+F(2)$ total & 0,853 \\
\hline
\end{tabular}

The parameter value of 1 determines the formalized condition of a completely functioning public transport system in terms of the passenger transport service quality. This parameter can be measured in percents, but it can also be a relative value.

\section{Conclusion}

Analysis of sources on the quality of passenger transportation services showed the absence of a parameter that would take into account the requirements of passengers. Most of the existing evaluation criteria consider only the technological, technical or economic aspects of the passenger transportation process.

Taking into account the above-stated as an indicator of the service reliability, the probability of the passenger's arrival to the destination point has been suggested under actual limitations - the vehicle headway and its standard deviation. Resulting from of the technique, it is possible to evaluate the reliability of both single modes of the urban passenger transportation and the system reliability as a whole.

The further research is to perform a representative survey for, at least, one public transportation mode with aim of determining a general reliability indicator.

\section{References}

1. Роїна О.М. Автомобільний транспорт в Україні. Нормативна база / О.М. Роїна. К. : Атіка, 2004. - 504 с. 
2. Закон України «Про міський електричний транспорт»: Режим доступу: http: // zakon3.rada.gov.ua/laws/show/en/1914-15 (accessed 06.04.2016).

3. Поначугин В.А. Оценка надежности перевозочного процесса городского пассажирского транспорта / В.А. Поначугин. - Н. Новгород: Нижегородский государственный архитектурно-строительный университет, 2008. - 92 с.

4. Мартынов Н.Г. Методологические аспекты комплексной оценки эффективности работы транспорта / Н.Г Мартынов // ВИНИТИ. Обзорная информация. Транспорт, наука, техника, управление. - 1999. - № 4. - C. 4-8.

5. Inta M. Researchs on reliability of urban passenger transport in Sibiu / M. Inta, A. Muntean // Annals of the Oradea university. Fascicle of Management and Technological Engineering. - 2015. - Issue 1. - P. $79-82$.

6. Tseng Y. Valuation of travel time reliability in passenger transport / Y. Tseng. - Amsterdam: Rozenberg Publishers, 2008. - 187 p.

7. Vincent M. Measurement Valuation of Public Transport Reliability / M. Vicent. - Wellington: Land Transport New Zealand, 2008. - 128 p.

8. Семчугова Е.Ю. Определение весомости показателя надежности транспортных услуг в качестве перевозок / Е.Ю. Семчугова, В.В. Зырянов, П.П. Володькин // Науковедение: Интернет-журнал. 2012. - № 4. - Режим доступу: http://cyberleninka.ru/article/n/opredelenievesomosti-pokazatelya-nadezhnostitransportnyh-uslug-v-kachestve-perevozok.

9. Кужель В.П. Визначення рівня якості пасажирських перевезень 3 позиції пасажира / В.П. Кужель, А.П. Іщенко, М.О. Бишко // Вісник СНУ ім. В. Даля. 2013. - № 15 (204). - C. 12-16.

10. Вініченко В.С. Аналіз факторів і умов, які впливають на якість пасажирських перевезень на міському пасажирському транспорті / В.С. Вініченко, І.Ю. Тарасюк // Комунальне господарство міст. 2011. - № 99. - С. 369-374.

11. Аулін В.В. Якість перевезень пасажирів як невід'ємна частина транспортного процесу / В.В. Аулін, Д.В. Голуб // Вісник КДПУ ім. Михайла Остроградського. - 2008. - Вип. 5 (52). - С. 80-84.

12. Тлегенов Б.Н. Анализ методов оценки и показателей качества системы городского пассажирского транспорта / Б.Н. Тле- генов // Современные проблемы науки и образования. - 2012. - № 3. - С. 100-108.

13. Большаков A.M. Повышение качества обслуживания пассажиров и эффективности работы автобусов / А.М. Большаков, Е.А. Кравченко, С.Л. Черникова. М.: Транспорт, 1981. - 206 с.

14. Цибулка Я. Качество пассажирских перевозок в городах / Я. Цибулка. - М.: Транспорт, 1987. - 240 с.

15. Kouwenhoven M. New values of time and reliability in passenger transport in the Netherlands / M. Kouwenhoven, G.C. De Jong, P. Koster // Research in Transportation Economics. - 2014. - №. 47. P. 37-49 .

16. Анохин С.А. Статистические методы оценки качества перевозочного процесса городского общественного автотранспорта / С.А. Анохин // Архитектура и строительство. Транспорт. - 2012. № 4 (42) - C. 35-43.

17. Гудков В.А. Технология, организация и управление пассажирскими автомобильными перевозками / Л.Б. Миротин, В.А. Гудков - М.: Транспорт, 1997. $254 \mathrm{c}$.

18. Горбачов П.Ф. Дослідження інтервалів руху на міському автобусному маршруті / П.Ф. Горбачов, Д.М. Копитков // Коммунальное хозяйство городов. - 2007. № 76. - С. 336-344.

19. Минько А.А. Статистический анализ в MS Excel / A.A. Минько. - М.: Диалектика, 2004. - $448 \mathrm{c}$.

20. Халафян A.A. Statistica 6. Статистический анализ данных / А.А. Халафян. - М.: Бином-Пресс, 2007. - 512 с.

21. Гмурман В.Е. Теория вероятностей и математическая статистика / В.Е. Гмурман. - М.: Высшая школа, 2003. - 479 с.

22. Спирин И.В. Перевозки пассажиров городским транспортом / И.В. Спирин. М.: Академкнига, 2004. - 413 с.

23. Горбачов П.Ф. Оцінка реакції пасажира на час очікування міського пасажирського транспорту / П.Ф. Горбачов, Д.М. Копитков // Восточно-Европейский журнал передовых технологий. 2008. - № 2 (31). - C. 40-42.

\section{References}

1. Royina O.M. Avtomobil'nyy transport $v$ Ukrayini. Normatyvna baza [Road transport in Ukraine. Normative base], Kiev, Atika Publ., 2004. 504 p. 
2. Zakon Ukrayiny «Pro mis'kyy elektrychnyy transport» [Law of Ukraine «On urban electric transport»]. Available at: http://zakon3.rada.gov.ua/laws/show/en/19 14-15 (accessed 03.04.2017).

3. Ponachugin V.A. Otsenka nadezhnosti perevozochnogo protsessa gorodskogo passazhirskogo transporta [The transportation process reliability evaluation of the urban mass transit], Nizhniy Novgorod, Nizhny Novgorod State University of Architecture and Civil Engineering Publ., 2008, 92 p.

4. Martynov N.G. Metodologicheskie aspekty kompleksnoi otsenki effektivnosti raboty transporta [Methodological aspects of the integrated transport performance assessment], VINITI. Overview information. Transportation, science, technology, management, 1999, no. 4, pp. 4-8.

5. Inta M., Muntean A. Researchs on reliability of urban passenger transport in Sibiu // Annals of the Oradea university. Fascicle of Management and Technological Engineering, 2015, no. 1, pp. 79-82.

6. Tseng Y. Valuation of travel time reliability in passenger transport. Amsterdam, Rozenberg Publishers, 2008. $187 \mathrm{p}$.

7. Vincent M. Measurement Valuation of Public Transport Reliability. Wellington, Land Transport New Zealand, 2008. 128 p.

8. Semchugova E.Yu., Zyryanov V.V., Volod'kin P.P. Opredelenie vesomosti pokazatelya nadezhnosti transportnykh uslug $v$ kachestve perevozok [Determination of the reliability indicator weight in the transportation service quality]. Naukovedenie, 2012, no. 4. Available at: http:// cyberleninka.ru/article/n/opredelenie-vesomostipokazatelya-nadezhnosti (accessed 29.03.2017).

9. Kuzhel' V.P., Ishchenko A.P., Byshko M.O. Vyznachennya rivnya yakosti pasazhyrs'kykh perevezen' z pozytsiyi pasazhyra [Determination of the passenger transportation quality level from the passenger's viewpoint]. Visnyk SNU [SNU Bulletin], 2013, no. 15 (204). pp. 12-16.

10. Vinichenko V.S., Tarasyuk I.Yu. Analiz faktoriv i umov, yaki vplyvayut' na yakist' pasazhyrs'kykh perevezen' na mis'komu pasazhyrs'komu transporti [Analysis of factors and conditions affecting the quality of urban passenger transportation]. Котиnal'ne hospodarstvo mist [Urban municipal engineering], 2011, no. 99, pp. 369-374.
11. Aulin V.V., Holub D.V. Yakist' perevezen' pasazhyriv yak nevid»yemna chastyna transportnoho protsesu [The passenger transportation quality as an integral part of the transportation process]. Visnyk KDPU im. Mykhayla Ostrohrads'koho. [Mykhaylo Ostrohrads'kyi KDPU Bulletin], 2008, no. 5 (52), pp. 80-84.

12. Tlegenov B.N. Analiz metodov otsenki $i$ pokazatelei kachestva sistemy gorodskogo passazhirskogo transporta [Analysis of assessment methods and quality indicators of the urban passenger transport system]. Sovremennye problemy nauki i obrazovaniya [Current problems of science and education], 2012, no. 3, pp. 100-108.

13. Bol'shakov A.M., Kravchenko E.A., Chernikova S.L. Povyshenie kachestva obsluzhivaniya passazhirov i effektivnosti raboty avtobusov [Improving the quality of passenger service and bus performance], Moscow, Transport Publ., 1981. 206 p.

14. Tsibulka Ya. Kachestvo passazhirskikh perevozok $v$ gorodakh [Passenger urban transportation quality], Moscow, Transport Publ., 1987. 239 p.

15. Kouwenhoven M., De Jong G.C., Koster P. New values of time and reliability in passenger transport in the Netherlands. Research in Transportation Economics, 2014, no. 47, pp. 37-49.

16. Anokhin S.A. Statisticheskie metody otsenki kachestva perevozochnogo protsessa gorodskogo obshchestvennogo avtotransporta [Statistical methods to evaluate the quality of the urban mass transit transportation process]. Arkhitektura $i$ stroitel'stvo. Transport [Architecture and construction. Transport], 2012. no. 4 (42). pp. 35-43.

17. Gudkov V.A., Mirotin L.B. Tekhnologiya, organizatsiya $i$ upravlenie passazhirskimi avtomobil'nymi perevozkami [Technology, organization and management of passenger road transportation], Moscow, Transport Publ., 1997. 254 p.

18. Horbachov P.F., Kopytkov D.M. Doslidzhennya intervaliv rukhu na mis'komu avtobusnomu marshruti [Headway study on the urban bus route]. Kommunal'noe khozyaystvo horodov [Urban municipal engineering], 2007, no. 76. pp. 336-344.

19. Min'ko A.A. Statisticheskii analiz v MS Excel [MS Excel Statistical Analysis], Moscow, Dialektika Publ., 2004. - 448 p.

20. Khalafyan A.A. Statistica 6. Statisticheskii analiz dannykh [Statistica 6. Data statistical 
analysis], Moscow, Binom-Press Publ., 2007. 512 p.

21. Gmurman V.E. Teoriya veroyatnostei $i \mathrm{ma}-$ tematicheskaya statistika [Probability theory and mathematical statistic], Moscow, Vysshaya shkola Publ., 2003. 479 p.

22. Spirin I.V. Perevozki passazhirov gorodskim transportom [Urban passenger transportations], Moscow, Akademkniga Publ., 2004. $413 \mathrm{p}$.

23. Horbachov P.F. Kopytkov D.M. Otsinka reaktsiyi pasazhyra na chas ochikuvannya mis'koho pasazhyrs'koho transportu [Passenger's response evaluation to the public passenger transportation waiting time]. Vostochno-Evropeyskyy zhurnal peredovykh tekhnolohyy [Eastern-European Journal of Enterprise Technologies], 2008, no. 2 (31), pp. 40-42.

Рецензент: Е.В. Нагорный, профессор, д.т.н., ХНАДУ 